\title{
Social Support Pada Anak Penderita Penyakit Terminal
}

\author{
Relung Fajar Sukmawati \\ relungfs@gmail.com
}

\author{
Nur Amalia Hamida \\ $\underline{16410046 @ \text { student.uin.malang.ac.id }}$
}

\author{
Rizka Amalia \\ 16410070@student.uin-malang.ac.id
}

\author{
Fathul lubabin Nuqul \\ lubabin-nuqul@uin-malang.ac.id
}

Fakultas Psikologi, Universitas Islam Negeri (UIN) Maulana Malik Ibrahim Malang, Indonesia

\begin{abstract}
Patients with terminal diseases who die every year are increasing, especially cancer is predicted to increase. Cancer is the second higest reason of death in the age range of children after an accident. Children who are diagnosed with cancer will certainly limit the activities normally carried out by their age. This is because their time is passed a lot to go through the treatment process that is not short. Therefore, children with terminal disease need support from the closest people who accompany them in the treatment process. The purpose of this study was to determine the role of social support in children with terminal disease. This research was conducted at the Syaiful Anwar Malang hospital, precisely the Pavilium building on the IRNA IV in a special room used to play for terminal's patient which is managed by the Sahabat Anak Cancer. This research uses a case study approach and involves 3 children with terminal disease as the subject of research. The results showed that the social support provided by care giver was able to foster a spirit of positive future expectations for patients.
\end{abstract}

Keyword : terminal disease; social support; future orientation.

Psikoislamika : Jurnal Psikologi dan Psikologi Islam (JPPI) Volume 15. Nomor 2, Tahun 2018. copyright () 2018. Pusat Penelitian dan Layanan Psikologi.

\section{PENDAHULUAN}

Kematian merupakan peristiwa yang tidak terelakkan dalam kehidupan manusia, termasuk anak-anak. Pasien penyakit terminal anak divonis memiliki presentase harapan hidup yang relatif tidak tinggi. Penyakit terminal bersifat progresif atau dengan kata lain penyakit yang menuju ke arah kematian (White, 2002). Penyakit yang termasuk dalam penyakit terminal adalah penyakit kanker, penyakit degenertif, penyakit paru obstruktif kronis, stroke, parkinson, gagal jantung, penyakit genetika, dan penyakit infeksi seperti HIV AIDS (Kementerian Kesehatan RI, 2007).

Awal 2017 lalu menteri kesehatan memprediksi akan ada hampir 9 juta orang meninggal di seluruh dunia akibat kanker dan akan terus meningkat mencapai 12 juta orang setiap tahunnya pada 2030. Prevelensi penyakit kanker di Indonesia juga sudah cukup tinggi Pada 2013 lalu, 1.4 per 100 penduduk atau sekitar 347.000 orang adalah prevelensi kanker di Indonesia menurut Riskesdes. Pada tahun 2014 dan 2015 adanya peningkatan jumlah kasus kanker yang ditangani berdasarkan data BPJS Kesehatan. Rata-rata prevalensi kanker di Indonesia menduduki angka 1.4\%, dan Jawa Timur mencapai angka prevalensi yang cukup tinggi karena berada diatas rata-rata angka nasional yaitu 1.6\% (DepKes, 2017).

Dikutip dari Union for International Cancer Control (UICC), bahwa setiap tahunnya terdapat sekitar 176.000 anak yang didiagnosis kanker, yang 
didominasi oleh negara yang penghasilan rendah dan menengah. Kanker menjadi penyebab utama kematian dari 90.000 anak pada tiap tahunnya. Dinegara dengan pengahasilan menengah keatas, kanker menjadi penyebab kedua terbesar kematian anak dengan usia 5-14 tahun, setelah cedera dan kecelakaan. Sedangkan, di Indonesia terhitung sekitar 11.000 kasus kanker anak per tahunnya, dan ada sekitar 650 kasus kanker anak di Jakarta (Kemenkes RI, 2015).

Anak yang didiagnosis menderita penyakit terminal tentunya akan membatasi aktivitas yang lazimnya dilakukan oleh anak seusianya. Waktu bermain dan belajar mereka berkurang drastis karena harus menjalani pengobatan. Di rumah sakit Syaiful Anwar Malang, tepatnya gedung Pavilium pada bangsal IRNA IV dapat ditemukan satu ruangan khusus digunakan untuk bermain yang dikelola oleh Sahabat Anak Kanker. Mas R, salah satu relawan Sahabat Anak Kanker menuturkan pada tanggal 24 Maret 2018 jika ruang bermain ini dibangun sebagai upaya meminimalisir kebosanan pasien anak penyakit terminal yang harus dirawat di rumah sakit, terutama sampai berbulan-bulan lamanya.Berdasarkan uraian diatas dan minimnya data hasil penelitian tentang dampak dukungan sosial bagi pasien anak penyakit terminal, peneliti tertarik untuk mengkaji mengenai dampak social support bagi anak penderita penyakit terminal.

\section{METODE}

Penelitian ini dilakukan dengan menggunakan pendekatan kualitatif. Metode kualitatif merupakan metode yang menuntut peneliti untuk membuat suatu usaha dalam memahami sesuatu realitas organisasi tertentu dan fenomena yang terjadi dari perspektif pada semua pihak yang terlibat (Jonker, 2011).

Jenis penelitian yang digunakan dalam penelitian ini adalah jenis studi kasus. Sayekti Pujosuwarno (1986: 1) mengemukakan pendapat dari Moh. Surya dan Djumhur yang menjelaskan bahwasanya studi kasus sebagai suatu teknik dalam mempelajari individu secara lebih mendalam yang nantinya dapat menjadikan individu tersebut terbantu dalam penyesuaian diri yang baik. Subjek dalam penelitian adalah pasien dan lingkungan sekitar baik itu orang tua, keluarga, pasien lain maupun material dari social support disekitarnya yang berada di Rumah Sakit Syaiful Anwar Kota
Malang. Kriteria subjek dalam penelitian ini adalah pasien anak dengan rentang usia 4-11 tahun yang telah didiagnosa oleh dokter secara medis sebagai pasien penderita penyakit terminal. Teknik pengumpulan data yang dipakai dalam penelitian ini adalah observasi dan wawancara. Observasi yang digunakan adalah observasi pastisipan. Dimana peneliti/observer ikut andil dalam kegiatan yang dilakukan oleh objek. Kemudian wawancara dilakukan secara langsung, semi terstruktur, dan informal.

Wawancaran dilakukan dalam dua bentuk, yaitu (1) wawancara langsung kepada orang tua dan relawan (2) wawancara proyeksi kepada anak penderita penyakit terminal. Wawancara proyeksi dilakukan dengan cara memberikan selembar kertas kepada anak dan meminta anak untuk mewarnai yang berkaitan dengan rumah dan profesi, seperti dokter, guru dan polisi. Kemudian hasil gambar anak dianalis.

\section{HASIL DAN DISKUSI}

\section{Pengkategorian Umum}

Dalam penelitian ini, terdapat tiga pasangan (Ibu dan anak) yang menjadi subjek penelitian, ditambah dengan wawancara pada satu relawan untuk mendapatkan informasi lebih dalam mengenai pasien penyakit terminal anak.Ketiga pasien penyakit terminal anak berusia lima sampai tujuh tahun, berasal dari daerah pedalaman yang jauh dari kota Malang. Kondisi ekonomi keluarga berada di posisi menengah ke bawah. Minimnya pengetahuan masyarakat yang berada di desa tempat tinggal pasien membuat mereka mengklaim jika penyakit terminal salah satunya kanker adalah penyakit yang menular.

Mengamati hasil penelitian metode wawancara, dua pasien penyakit terminal anak mengatakan jika mereka tidak betah tinggal di rumah sakit. Pernyataan tersebut akan dibuktikan dengan transkip wawancara berikut ini.

"Enggak, kangen rumah. Pingen pulang, pingen sekolah" (RH:4)

"Soalnya aku seneng di rumah"(ST:2), "dirumah banyak orang"(ST:4a), "ada teman-teman juga" (ST:4b) 
Sementara satu pasien penyakit terminal anak lainnya hanya merasa tidak betah pada awal perawatan, sebagaimana pernyataan ibunda pasien pada hasil wawancara berikut.

"Dulu pas pertama ya nangis mbak, pengen pulang” (N:8a). "Tapi sekarang, dibawa ke ruang ini (menunjuk ruang bermain) malah gak mau balik ke kamar mbak. Malah ini minta dianterin mbak, padahal habis kemo. Dia kalau pagi pasti nanyain udah buka belum bu" (N:8b)

Salah satu pasien dengan kode N, telah memasuki 5 tahun perawatan. Termasuk satu-satunya pasien anak penyakit terminal yang masih survive dibanding pasien anak penyakit terminal lainnya yang terlebih dahulu meninggal dunia. $\mathrm{N}$ sejak lahir sudah memiliki kelainan darah.

"Terus Nanda itu sejak lahir punya kelainan darah mbak. Sempat sembuh setelah dirawat sekitar 9 bulan sejak dia lahir" (N:6b). "Nah, ketika usia 3th 8 bulan Nanda demam tinggi selama 3-4 hari mbak. Saya bawa ke rumah sakit dan hasilnya dia leukimia stadium 2 mbak. Awalnya saya rawat jalan, tapi tidak konsisten mbak. Jadi dokter menyarkan dirawat inap. Iya ini, sampai sekarang mbak" (N:6c).

Sementara relawan yang menjadi subjek penelitian kami telah mengabdi si SAK (Sahabat Anak Kanker) sejak tahun 2011. Setiap hari SAK mempunyai jadwal khusus untuk adik-adik yang ingin bermain, dan jadwal tersebut disusun oleh Om Ferry selaku ketua SAK. Menurut relawan, kedua orang tua pasien anak penyakit terminal sudah optimal dam memberikan support. Hal tersebut dilihat dari kesetiaan orang tua mendampingi anaknya berobat meskipun ada yang sampai kehilangan pekerjaan. Semua dilakukan hanya untuk anak.

\section{Sumber dan Bentuk Social Support}

\section{a. Social Support Emosional}

Dalam penelitian ini didapatkan bentuk dukungan sosial berupa emosional. Dukungan emosional bersumber dari keluarga dan temanteman pasien. Ibu IR memilih untuk melepas pekerjaanya agar senantiasa menemani RH selama sebulan ini. Sama halnya dengan ibu IR, ayah dari
NA dipecat dari pekerjaannya karena menemani NA di rumah sakit. Sedangkan ST memiliki sumber dukungan emosional dari keluarga seperti ayah, ibu dan neneknya dan teman-teman sekolah ST pun ikut serta dalam memberikan dukungan emosional kepada ST dengan menjenguk ST ke rumah sakit.

Keberadaan keluarga pada sisi pasien memberikan semangat baru untuk sembuh pada pasien. Sebagaimana pernyataan seorang dokter Kanker dari Parkway Cancer Centre, Singapura bahwa "dukungan keluarga dan teman adalah hal paling krusial dalam penanganan kanker, karena pasien yang sudah didiagnosa itu sudah hancur mentalnya." (Vania, 2017).Dukungan emosional mencakup kehangatan, kepedulian dan empati yang didapatkan dari orang lain sehingga pasien akan merasa yakin bahwa dirinya diperhatikan oleh orang lain. Dukungan emosional dapat melindungi pasien dari dampak negatif akibat stres berat yang dialami pasien. Pasien yang memiliki dukungan sosial tinggi khususnya pada dukungan emosional akan sedikit menilai situasi atau keadaan yang dialaminya (stres) dan akan mengubah respon mereka terhadap sumber stres tersebut.

\section{b. Social Support Penilaian}

Social Support penilaian berupa pemberian reward (penghargaan positif) pada pasien. Hal ini sebagaimana yang dilakukan oleh nenek dari ST yang selalu memberikan pujian pada hasil mewarnai ST dan ST pun mengaku bahwa ia merasa bahagia ketika mendapat pujian dari nenek ataupun anggota keluarga lainnya.Sama halnya dengan ST, orang tua IR juga selalu memberi apresiasi kepada IR karena senantiasa terlihat ceria dan bahagia. Selama dalam observasi peneliti, IR bermain bersama teman-temannya dalam tawa dan bahagia.

Penilaian yang dilakukan oleh lingkungan pasien menjadi motivasi tersendiri bagi pasien terminal. Sehingga para pasien menjadi merasa mendapat kasih sayang dan perhatian yang lebih dari lingkungannya. Amier Dien Indrakusuma (1999) menyatakan bahwa pemberian hadiah baik itu berupa materil atau sekedar pujian dapat menjadikan peningkatan motivasi pada diri anak.

c. Social Support Instrumental 
Dukungan sosial berupa instrumental adalah dukungan yang diterima oleh individu secara nyata. Seperti yang ada di Ruang Bermain Sahabat Anak Kanker berupa mainan, buku bacaan, kertas gambar dan kertas mewarnai. Segala bentuk istrumental tersebut menjadi bagian dari dukungan sosial mereka sebagai pasien terminal. Adanya dukungan instrumental berupa barang-barang (materi) atau adanya pelayanan dari orang lain yang dapat membantu individu dalam menyelesaikan masalahnya.

Bentuk dukungan sosial instrumental yang didapat oleh pasien berupa kenyamanan pada ruang bermain sebagaimana yang dinyatakan oleh orang tua IR bahwa IR merasa lebih betah ketika dirawat di Rumah Sakit Saiful Anwar dikarenakan adanya fasilitas ruang bermain bagi pasien anak terminal dibanding dengan Rumah Sakit $\mathrm{X}$ tempat IR dirawat sebelumnya. Subyek $\mathrm{N}$ beberapa kali meminta orang tuanya untuk membacakan dongeng ketika d ruang rawat inap, dikarenakan ketika di ruang bermain relawan sering kali membacakan dongeng untuknya. Selain itu $\mathrm{N}$ juga membawa beberapa buku dongeng ke ruang rawat inapnya. Hal ini menunjukkan bahwa adanya ketertarikan subyek dengan pelayanan yang diberikan oleh relawan kepadanya.

Subyek ST menunjukkan adanya bentuk dukungan sosial yang ia terima denganantusias subyek ketika diminta mewarnai. Nenek dari ST menceritakan pada peneliti bahwa ST gemar mewarnai ketika dirumah. Sehingga saat mengetahui ruang bermain menyediakan fasilitas mewarnai menjadikan ST tidak larut dalam sedih terhadap dirinya.

\section{Orientasi Masa Depan}

Pada umumnya setiap manusia memiliki orientasi masa depan, tak terkecuali pasien penderita penyakit terminal. Rangkaian pengobatan panjang yang melelahkan dilakukan oleh penderita penyakit terminal memunculkan harapan untuk dapat kembali bersekolah dan bermain di rumah. Lingkungan sekolah bagi anak merupakan tempat belajar dan membangun pertemanan.

Sebagaimana dikatakan:

"Soalnya aku seneng dirumah. Di rumah banyak orang. Ada teman-teman sekolah juga" (ST).
Selain itu, adanya dukungan sosial yang diterima oleh pasien penderita penyakit terminal memunculkan harapan dan cita-cita yang berkembang secara positif di kalangan anak penderita penyakit terminal. Sebagaimana dikatakan :

"Pingen jadi dokter. Biar bisa nyembuhin orang sakit" (RH).

Penelitian Tromssdof (2009) menemukan bahwa dukungan sosial dan interaksi sosial yang terbina dalam keluarga berpengaruh pada orientasi masa depan anak terutama dalam menumbuhkan sikap optimis dalam memandang masa depannya. Hal ini dikarenakan orang tua atau keluarga yang menjadi caregiver anak penyakit terminal merupakan figur terdekat dalam mengahadapirangkaian pengobatan yang dilakukan.

\section{KESIMPULAN DAN SARAN}

Penyakit terminal adalah penyakit yang memiliki sedikit kemungkinan untuk sembuh. Pasien anak yang telah terdiagnosis penyakit terminal membutuhkan social support dari orangorang yang berada di sekitarnya, terutama orangorang yang dekat dengannya. Social support yang berusaha diberikan oleh kedua orang tua dan relawan SAK menumbuhkan semangat untuk sembuh bagi pasien, sebagian dari pasien juga menyatakan bahwa ia masih memiliki harapanharapan masa depan. Kami berharap terdapat penelitian lebih lanjut tentang optimalisasi social support yang telah diberikan oleh orang-orang terdekat yang berada di lingkungan sekitar pasien anak penyakit terminal. Bagi pemerintah, kami berharap mampu menyediakan tempat bermain disetiap rumah sakit yang terdapat perawatan untuk penyembuhan penyakit-penyakit terminal bagi pasien anak, sebagai salah satu bentuk social support instrumental.

\section{DAFTAR PUSTAKA}

APA. (2015). APA Dictionary of Psychology Second Edition. Washington DC: American PSychologi Asociation

Balnco, P.J,. \& Holliman, R.P,. \& Muro, J.H,. \& Toland, S,. \& Farnam, J.L.(2017). Longterm childcentered play therapy effects on academic 
achievement with normalfunctioning children.

J Child Fam Stud, 26:1915-1922

Cokroaminoto.(2014). Metodologi penelitian kualitatif.

Diakses taggal 18 Maret 2017 Jan, J., \&

Bartjan, J.W., \& Pennink, Wahyuni. (2011).

Metodelogi penelitian. Jakarta :salemba empat.

Kemp, C. (2010). Klien sakit terminal: Seri asuhan keperawatan, (2 ed). Jakarta: Penerbit Buku Kedokteran EGC

Ngastiyah. (2005). Perawatan anak asih. Jakarta: Penerbit Buku Kedokteran EGC

Nurmi, J.E. (1989). Development of orientation to the future during early adolescence: A four year longitudial study and two cross sectional comparisons. International Journal ofPsychology, 24(1-5), 195-214.

Rahayu., \& Ardani, I.T., \& Ardi, T,. (2004). Observasi dan wawancara. Malang: BayumediaPublishing

Taylor, S.E. (2009). Health psychology (7th ed). Boston : McGraw-Hill

Tie, S,. \& Poulsen, S. (2013). Emotionally focused couple therapy with couples facingterminal illness. Contemp Fam Ther (2013) 35:557567

Santrock, J.W. (2007). Perkembangan anak (7 ed). PT Gelora Aksara Pratama

Sarafino, E.P., \& Smith, T.W. (2011). Health psychology : Biopsychosocial interactionsseventh edition. New York: John Wiley \& Sons

Sories, F,. \& Maier, C,. \& Beer, A,. \& Thomas, V. (2015). Addressing the needs of military children through family-based play therapy. Contemp Fam Ther (2015) 37:209-220

Villar, M.A,. \& Keng, Y.H,. \& Calzada, E.J. (2017). Social support, parenting, and socialemotional development in young mexican and dominican american children. ChildPsychiatry Hum Dev, 48:597-609

White, P.G. (2002). Word hospice palliative care the loss of child day, pediatric heart network. www.hospiceinternational.com. ditelusuri pada tanggal 12 januari 2010 